\title{
Fragility of Red Blood Cells under 31 Atmosphere Absolute for 14 Days
}

\author{
Keizo SHIRAKI', Sueko SAGaWA', Nobuhide KONDA' ${ }^{1}$ and Hideaki NAKAYAMA ${ }^{2}$ \\ ${ }^{I}$ Department of Physiology, School of Medicine, University of Occupational and \\ Environmental Health, Japan. Kitakyushu 807, Japan \\ ${ }^{2}$ Department of Hyperbaric Medicine, School of Medicine, University of Occupational and \\ Environmental Health, Japan. Kitakyushu 807, Japan
}

Abstract: The present investigation was undertaken during the course of a 14-day dry saturation dive at 31 ATA to study hematologic changes and osmotic fragility of red blood cells in relation to lipid contents of the plasma and red cells. Increase in the hematocrit and blood cell count was observed in the early phase at 31 ATA, which was attributed to the hemoconcentration caused by the hyperbaric diuresis. Osmotic fragility of red blood cells fluctuated during the course of the experiment, but the change was not related to the atmospheric pressure. Cholesterol and phospholipid contents in red blood cells and the plasma also fluctuated but the change was not caused by the pressure. However, an overall correlation between the osmotic fragility and the phosphatidyl choline of red cells and the correlation between the osmotic fragility and the total cholesterol level in the plasma were observed at both 1 and 31 ATA. These correlations revealed an intimate relation between the red cell fragility and lipid composition of the cell membrane and the plasma within intra- and interindividual variations during the course of the dive. The present result did not indicate any significant alteration of red blood cell function due to prolonged exposure to 31 ATA $\mathrm{He}-\mathrm{O}_{2}$ environment.

Key words: dry saturation dive, osmotic fragility, red blood cell lipids, hemoconcentration.

(Received 4 November 1982)

\section{Introduction}

It is still unknown whether a chronic exposure of high pressure in a helium oxygen environment can be a stressor to alter the fragility of red blood cells (Rbc). Acute and shallow dives (Jacey et al., 1977 ; Smith \& Tappan, 1975) or in vitro experiments (Brewster et al., 1976; Fenn \& Boschen, 1971) show conflicting results in the changes in the fragility of red blood cells. The reports hitherto published seem to have mixed up the stress of hyperbaria with hyperoxia or the combination of hyperbaria and hyperoxia (Philp, 1974 ; Macdonald, 1981). Hyperoxia increases a susceptibility for hemolysis by lipid peroxidation in the etiology (Mengel \& Kann, 1966). In practically all simulated saturation diving experiments, it is customary to maintain the $\mathrm{O}_{2}$ pressure of the chamber gas at 0.3 atmosphere absolute (ATA). Effects of chronic exposure of high pressure at a slightly higher than normal $\mathrm{O}_{2}$ pressure on $\mathrm{Rbc}$ must be different from that of hyperbaric hyperoxia or acute and repeated exposures to compression-decompression. Goldinger et al. 
(1980) reported a consistent reduction of red cell membrane permeability to $\mathrm{Na}$ and $\mathrm{K}$ under high hydrostatic pressure in vitro. The finding suggests that the red cell membrane transport function as well as the intracellular ionic composition are altered at high pressure. If so, it is possible that the osmotic fragility and the membrane lipid contents could also be altered in a hyperbaric environment. Red cells alter their osmotic fragility by chemical changes in the plasma and the cell membrane. Among these, lipid contents of red cell membrane connect most intimately with the shape and osmotic fragility of Rbc (Sagawa \& Shiraki, 1978a ; Sagawa \& Shiraki, 1980). Stressors to alter the cell fragility, such as strenuous exercise (sports anemia) (Yoshimura et al., 1980), malnutrition (Shiraki et al., 1976 ; Sagawa \& Shiraki, 1978b) and thermal stress (Kuiper et al., 1971 ; Zarkowsky et al., 1975) induce an associated change in the lipid content of Rbc.

The present investigation was undertaken during the course of a 14-day dry saturation dive at 31 ATA to study the fragility of $\mathrm{Rbc}$ in relation with content changes of lipids in $\mathrm{Rbc}$ and the plasma in human divers.

\section{Methods}

Four healthy male volunteer divers stayed in a hyperbaric chamber of $7.5 \mathrm{~m}$ long and $2.3 \mathrm{~m}$ in diameter in the Japan Marine Science and Technology Center, Yokosuka, Japan. The physical characteristics of the subjects are listed in Table 1. The experiment was undertaken from the 30th of July to the 31st of August, 1979. The overall dive profile of the experiment is shown in Fig. 1. During the 4-day pre-dive and 4-day post-dive periods, the subjects were breathing ambient air inside the chamber and the chamber temperature $\left(\mathrm{T}_{a}\right)$ and relative humidity $(\mathrm{rh})$ were controlled at $26 \pm 0.5^{\circ} \mathrm{C}$, and $60 \%$, respectively. The chamber pressure was first raised to 11 ATA over a period of 10 $\mathrm{h}$ with a constant rate of $10 \mathrm{~m}$ per $\mathrm{h}$, and maintained at this level for $14 \mathrm{~h}$. Using the identical schedule the chamber pressure was further increased to 21 ATA and then to 31 ATA, and the total time for completing the compression was $58 \mathrm{~h}$. The pressure was kept at 31 ATA for 14 days, and decompression was then carried out according to the standard US Navy schedules. Twelve days were required to complete the depression. The chamber temperature at 31 ATA was maintained at $31.0 \pm 0.2^{\circ} \mathrm{C}$. At 31 ATA, constant partial pressure of oxygen of 0.4 ATA and nitrogen of 0.79 ATA was maintained, and that of carbon dioxide was reduced to less than 0.004 ATA. The atmosphere was balanced with helium.

Calorie intake ranged from 2,800 to $3,000 \mathrm{kcal}$ per day throughout the dive and water balance and body weight of the divers were checked daily.

The details of the energy and fluid balances of this experiment were published elsewhere (Nakayama et al., 1981). Twenty $\mathrm{ml}$ of venous blood was withdrawn from the antecubital vein at $0630 \mathrm{~h}$ every $2-3$ days. The date is indicated also in Fig. 1 . Immediately after withdrawing the blood, it was mixed with EDTA-2K and was placed in 
Table 1. Physical characteristics of the subjects

\begin{tabular}{cccc}
\hline Subject & Age $($ yrs $)$ & Height $(\mathrm{cm})$ & Weight $(\mathrm{kg})$ \\
\hline K. M. & 28 & 168.5 & 59.5 \\
S. O. & 31 & 167.7 & 61.6 \\
T. F. & 35 & 168.2 & 61.5 \\
S. M. & 25 & 180.5 & 73.5 \\
\hline
\end{tabular}

\begin{tabular}{l|l|l} 
Pre-dive & Saturation & Decompression
\end{tabular} Post-dive

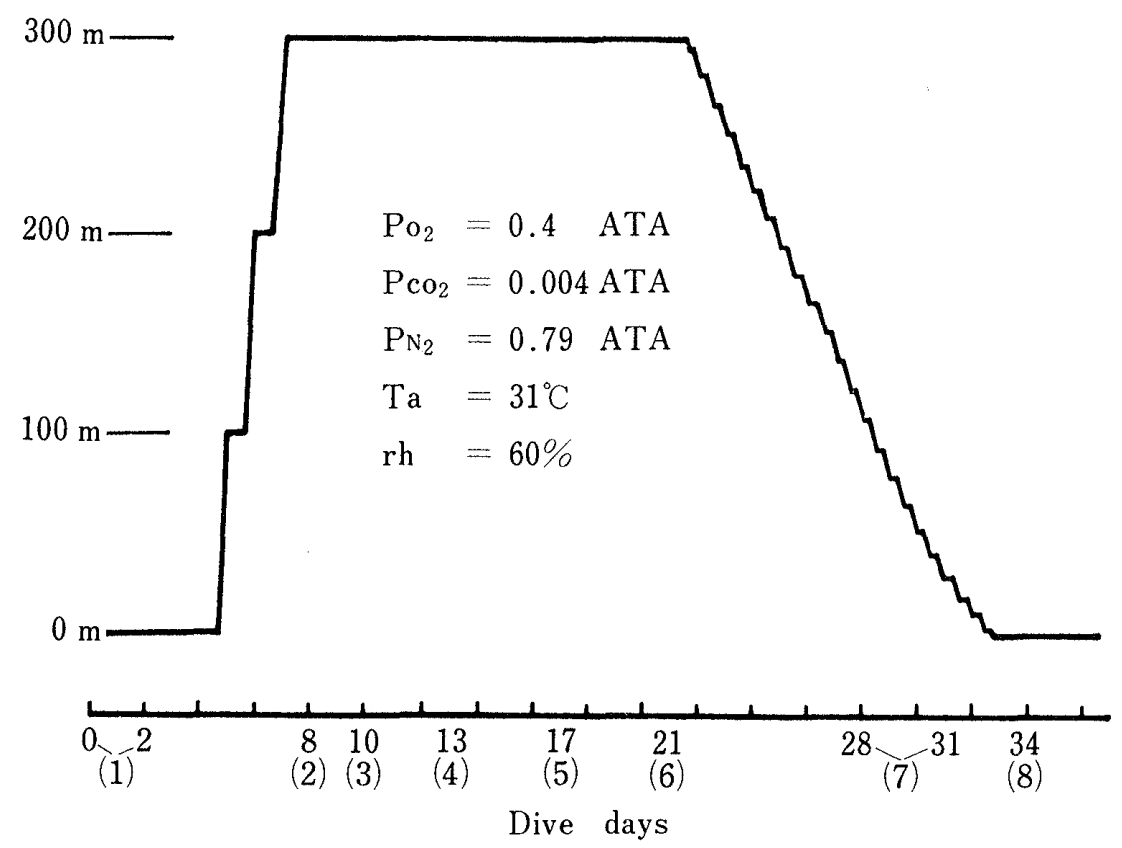

Fig. 1. Dive profile and partial pressures of chamber gas. Dive days on the abscissa also indicate the days of blood drawing from the divers. Number in the parenthesis indicates the sample number. Data of dive days 0 and 2 (pre-dive control), and 28 and 31 (decompression) are listed as sample number 1 and 7 , respectively.

ice in a small decompression chamber which was specially designed for transferring the samples through the medical lock to outside the chamber. The small decompression chamber was decompressed gradually (in approximately one $\mathrm{h}$ ) in a refrigerator $\left(5^{\circ} \mathrm{C}\right.$ ) to transfer the samples for analysis. Hematologic changes, if any, during the decompression procedure were checked as follows. Twenty $\mathrm{ml}$ each of blood were withdrawn from 5 healthy subjects outside the chamber, and the sample was divided into 2 groups. The hematologic parameters of one group were measured immediately after the blood with- 
drawing, and the samples of the other group were transferred into the chamber through the medical lock and placed in the chamber (31 ATA) for $30 \mathrm{~min}$. Then the samples were again transferred to 1 ATA by the same procedure by using the small decompression chamber as described above.

Red blood cells were counted with a microcell counter (Toa-Microcell Counter CC108, Kobe, Japan), hemoglobin concentration of the blood was measured by the cyanmethemoglobin method, and the hematocrit value was measured by the capillary method. Indices were calculated for mean corpuscular volume (MCV), mean corpuscular hemoglobin $(\mathrm{MCH})$, and mean corpuscular hemoglobin concentration (MCHC). Osmotic fragility of Rbc was measured in a series of hypotonic saline solutions (Hisaoka \& Shiraki, 1974), and the results were expressed by the concentration of $\mathrm{NaCl}$ which gives $50 \%$ hemolysis, which is termed as the half hemolysis rate (HHR). EDTA-blood was centrifuged at $1,500 \mathrm{~g}$ for $10 \mathrm{~min}$ at $5^{\circ} \mathrm{C}$ and then the red cells were washed three times with cold isotonic phosphate buffer $(\mathrm{pH} \mathrm{7.4)}$ to remove white cells and platelets. The washed red cells were suspended in $0.9 \% \mathrm{NaCl}$ at a density corresponding to the original hematocrit value, and samples were taken to measure the packed cell volume and lipid contents.

Lipids were extracted from the red cells and the plasma with a mixture of two volumes of chloroform and one volume of methyl alcohol (Folch et al., 1957), and portions of the extracts were used to measure total cholesterol, free cholesterol (Zack et al., 1954), and total phospholipids (Saliman, 1964). Values for cell lipids were expressed on the basis of the volume (in $\mathrm{ml}$ ) of packed cells. Percentage change in plasma volume during the dive was estimated by the formula of van Beaumont (1972).

The quantitative separation of phospholipids in red cells and the plasma was made by using a thin-layer chromatography (Skipski et al., 1964).

\section{Results}

Hematologic parameters during the dive are summarized in Table 2. Rbc count and hematocrit value increased significantly on the 8 th and the 10th days of the dive. The hematocrit value maintained an elevated level until the 17th day of the dive. After that it returned to the pre-dive level on the 21 st day. During the post-dive period hematologic parameters recovered to the pre-dive levels. The hemoglobin concentration tended to increase on the 8 th and 10th day, but the increase was not significant. MCV, MCH and MCHC did not change during the experiment. The plasma volume estimated from the hematocrit value is summarized in Fig. 2. The change in plasma volume is expressed as percent change from pre-dive value $(\% \Delta \mathrm{PV})$. A significant reduction of plasma volume was observed on the 8 th through 17 th day of the dive ranging from $3.9 \%$ to $9.3 \%$. The peak reduction of plasma volume (hemoconcentration) was observed on the 10 th day, after that the plasma volume gradually returned to the pre-dive control 


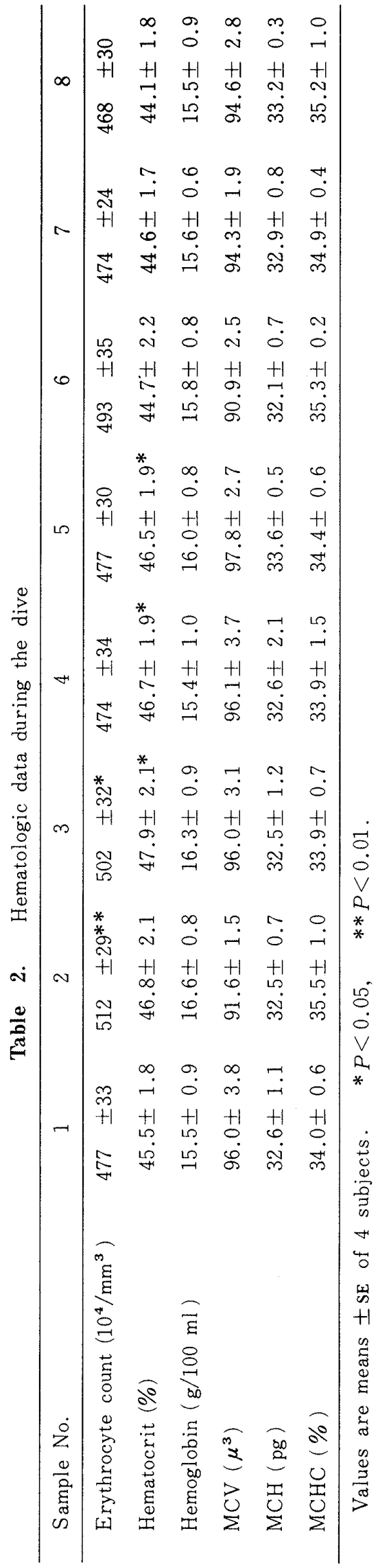




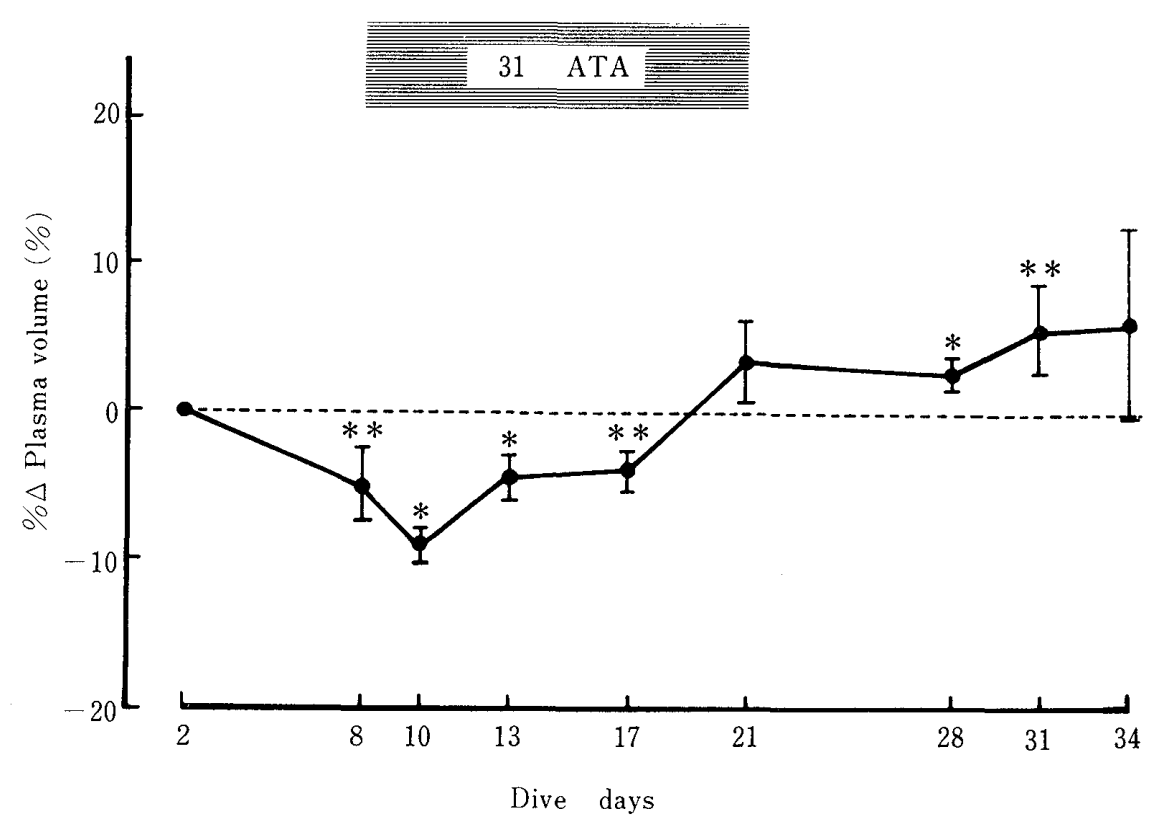

Fig. 2. Change in plasma volume. The change in plasma volume was expressed as percent deviation from the pre-dive $(\% \Delta \mathrm{PV})$. Points and vertical bars are means \pm SE of 4 subjects. $* P<0.05$ and $* * P<0.01$

level. After the 17th day of the dive the plasma volume tended toward gradual increase having the highest value (hemodilution) at the post-dive control period of 1 ATA.

The osmotic fragility of Rbc did not change significantly during the dive period, however it tended to decrease progressively during the course of the experiment (Fig. 3). The total amount of cholesterol in Rbc did not change significantly, but it had relatively wide daily fluctuations. The total phospholipid of Rbc was almost constant during the experiment except for a slight reduction on the 8th day of the dive. The molar ratio of total cholesterol to total phospholipid $(\mathrm{C} / \mathrm{P})$ of $\mathrm{Rbc}$ was constant throughout the experiment. Phosphatidyl choline of Rbc decreased during compression and revealed no recovery later on (Table 3 ).

Fig. 4 shows a relationship between the osmotic fragility and phosphatidyl choline in Rbc. In this figure, all values are included; those of pre-dive control, 31 ATA, decompression and post-dive control periods. Overall, the osmotic fragility and phosphatidyl choline of $\mathrm{Rbc}$ were independent of the chamber pressure. Total phospholipids and cholesterol in the plasma also did not change greatly throughout the experiment as summarized in Table 4. However, the amount of total cholesterol in the plasma had a significant correlation with the osmotic fragility of Rbc as shown in Fig. 5. In this figure, all values of pre-dive control, 31 ATA, decompression and post-dive control periods are included, and the figure suggests the correlationship between the osmotic fragility of $\mathrm{Rbc}$ and the total cholesterol level in the plasma is independent of the atmospheric 


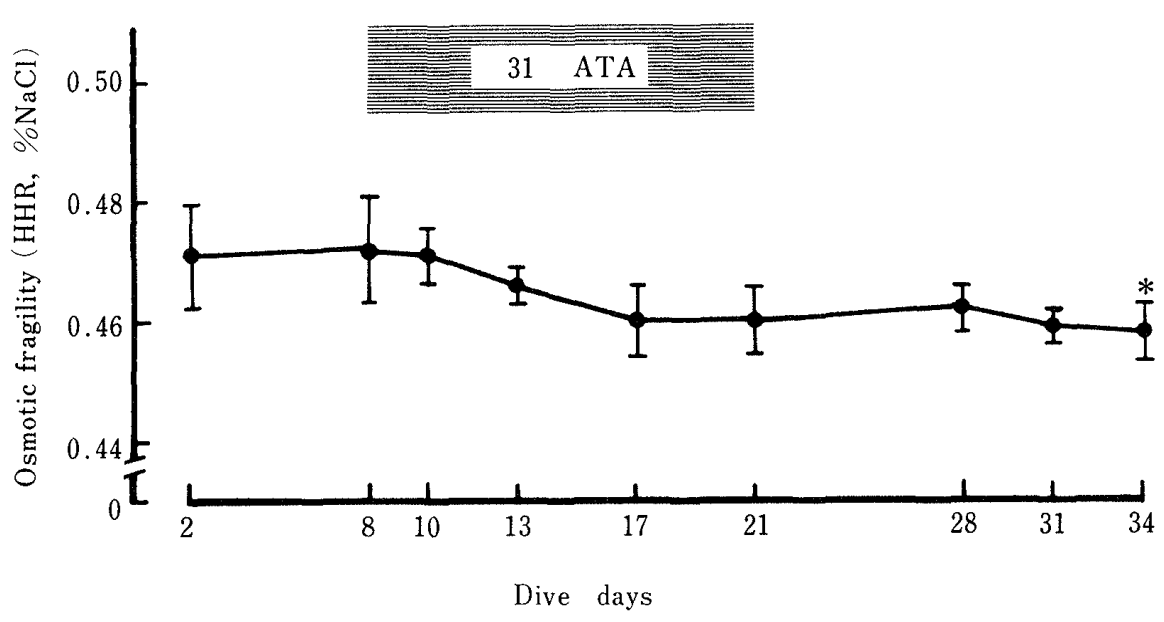

Fig. 3. Change in the osmotic fragility of red blood cells during the course of the dive. Points and vertical bars are means $\pm \mathrm{SE}$ of 4 subjects. HHR is the concentration of $\mathrm{NaCl}$ to give $50 \%$ hemolysis, for details see text.

$* P<0.05$

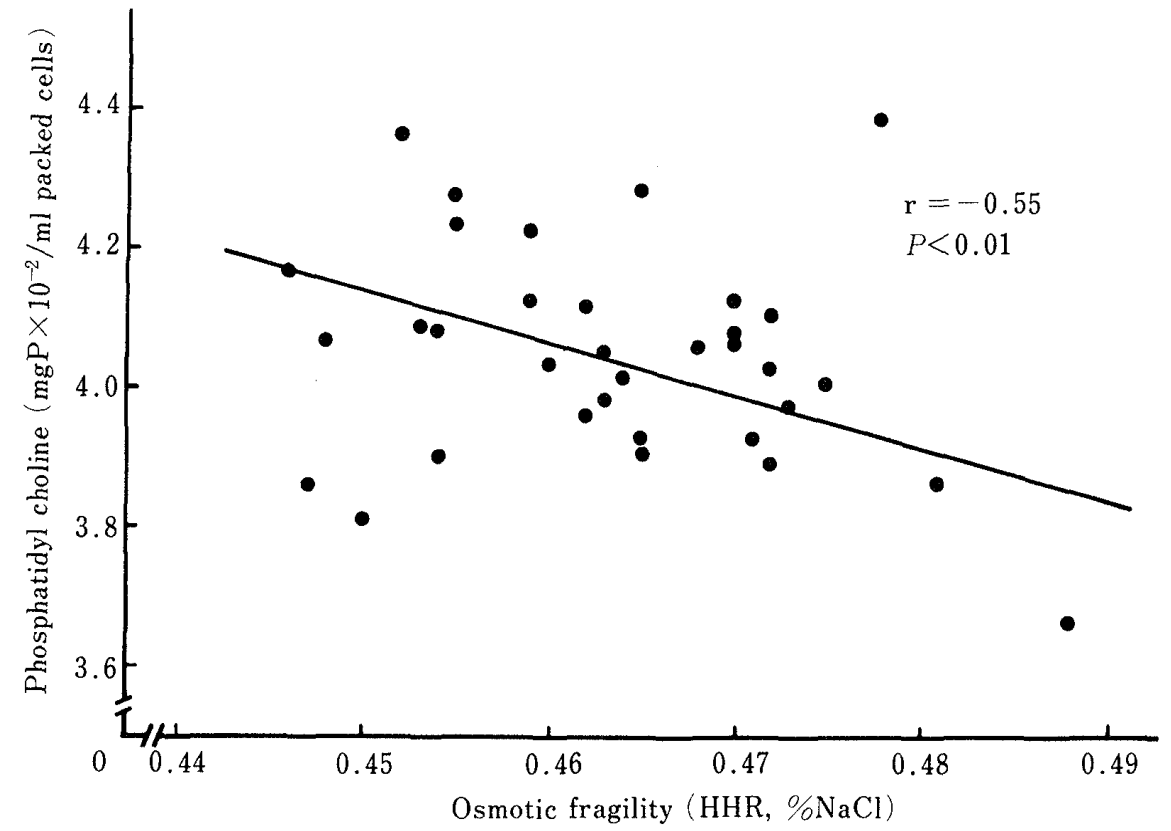

Fig. 4. Relationship between the osmotic fragility and the phosphatidyl choline content of Rbc. All values obtained during pre-dive control, 31 ATA, decompression and post-dive control periods are included in the figure. The regression line was calculated by the least square method.

pressure.

The osmotic fragility, lipids in Rbc and the hematocrit of the blood samples were not significantly altered by the decompression procedure as summarized in Table 5. 


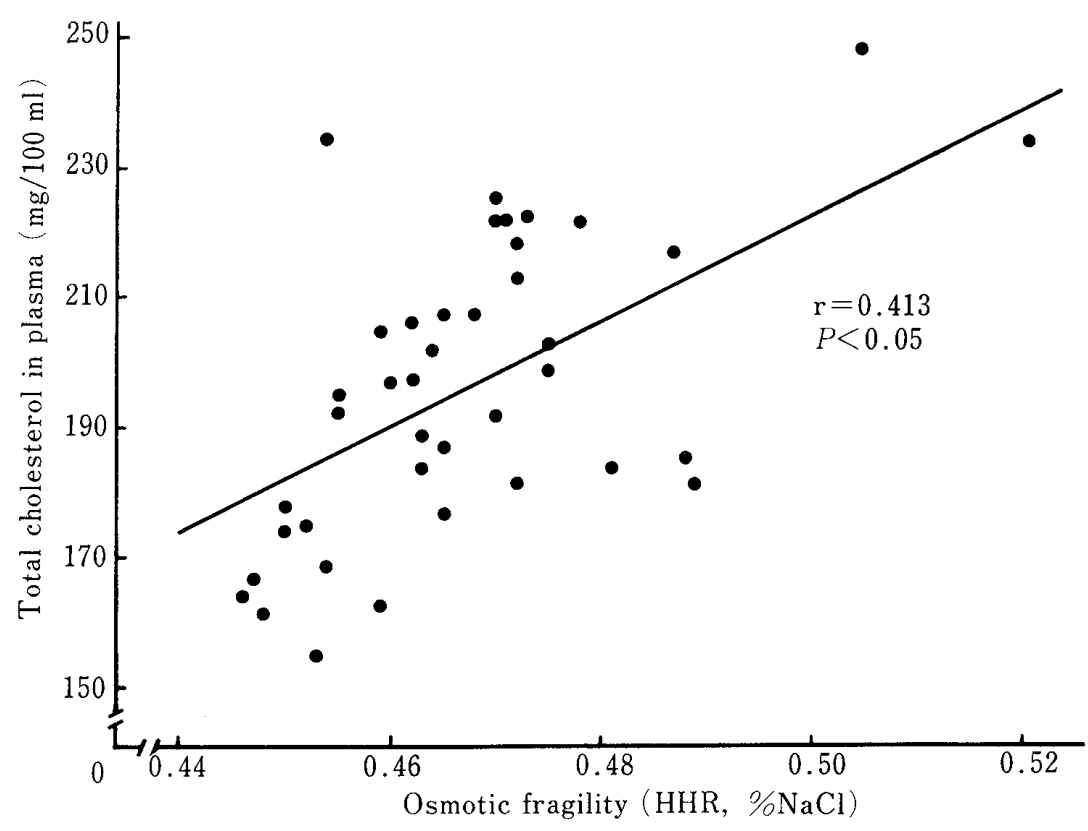

Fig. 5. Relationship between the osmotic fragility of $\mathrm{Rbc}$ and the total cholesterol level in the plasma. All values obtained during pre-dive control, 31 ATA, decompression and postdive control periods are included in the figure. The regression line was calculated by the least square method.

\section{Discussion}

In the present experiment, 4 divers were exposed to 31 ATA $\mathrm{He}-\mathrm{O}_{2}$ environment for 14 days, and revealed some hematologic changes. In addition to hyperbaria, there was a possibility that the subjects would be affected by multi-stressors such as prolonged confinement in the chamber, and psychological strain caused by an unusual thermal sensation in the $\mathrm{He}-\mathrm{O}_{2}$ environment (thermal discomfort).

In the present experiment, the divers stayed for 14 days at thermoneutral 31 ATA $\mathrm{He}_{2} \mathrm{O}_{2}$ environment and they felt comfortable thermally in the chamber. Therefore, at least thermal discomfort can be omitted as a possible stressor causing hematologic changes in the present experiment.

A large diuresis accompanied by a reduction of the body weight (by $0.7 \mathrm{~kg}$ on the average) was observed at 31 ATA of this experiment, especially during the early phase (Nakayama et al., 1981), strongly suggesting a net loss of body weight. The magnitude of decrease in plasma volume was estimated to be $10 \%$ on the 10 th dive day (Fig. 2).

The increase in the hematocrit and red blood cell count was most likely due to a mild dehydration caused by the diuresis at 31 ATA: the diuretic phenomenon at 31 ATA of the present experiment was already published elsewhere by the present authors (Nakayama et al., 1981). 


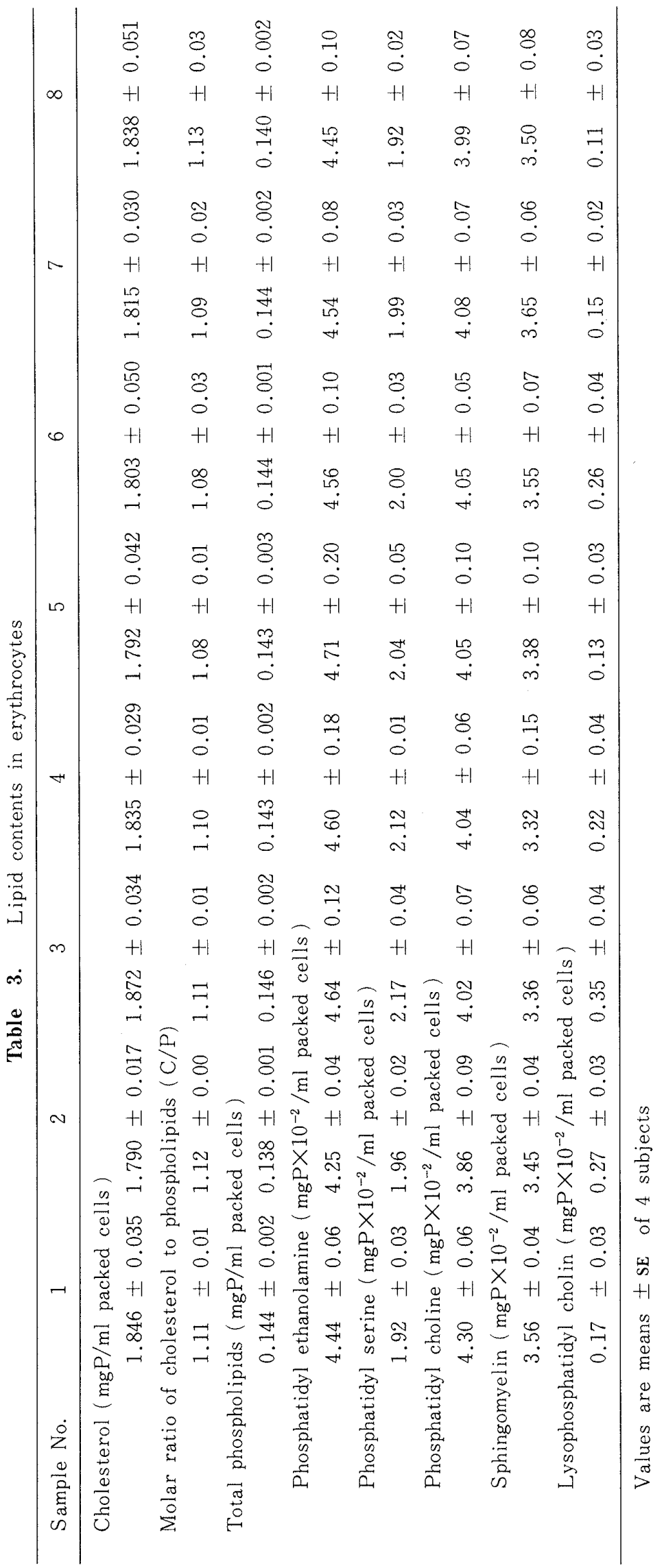




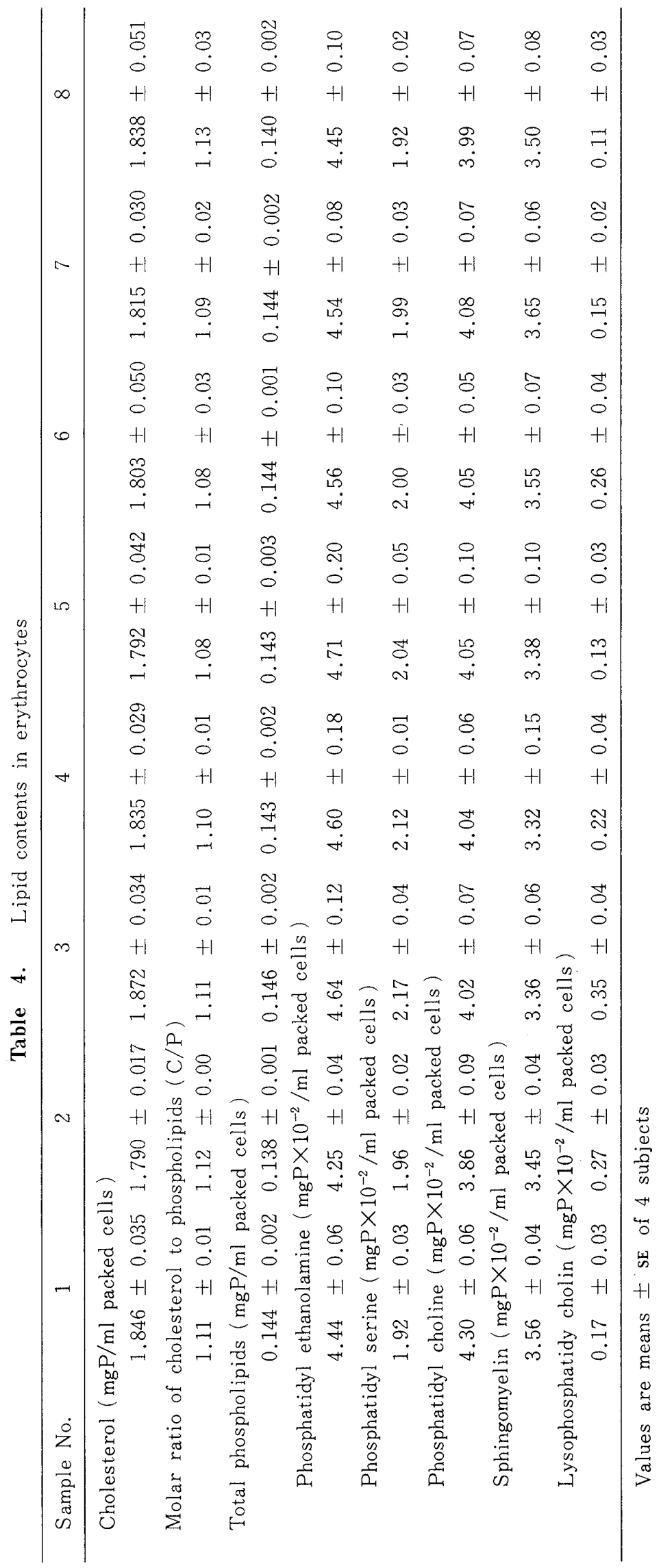


Table 5. Osmotic fragility, cholesterol and total phospholipids in red blood cells and the hematocrit before and after the decompression procedure

\begin{tabular}{ccccc}
\hline & $\begin{array}{c}\text { Osmotic fragility } \\
(\mathrm{HHR}, \% \mathrm{NaCl})\end{array}$ & $\begin{array}{c}\text { Cholesterol } \\
(\mathrm{mg} / \mathrm{ml} \text { packed cells })\end{array}$ & $\begin{array}{c}\text { Total phospholipids } \\
(\mathrm{mg} / \mathrm{ml} \text { packed cells })\end{array}$ & $\begin{array}{c}\text { Hematocrit } \\
(\%)\end{array}$ \\
\hline Before & $0.488 \pm 0.014$ & $1.872 \pm 0.048$ & $0.152 \pm 0.003$ & $45.45 \pm 1.40$ \\
After & $0.487 \pm 0.013$ & $1.860 \pm 0.043$ & $0.150 \pm 0.001$ & $45.46 \pm 1.391$ \\
\hline
\end{tabular}

Values are means $\pm \mathrm{SE}$ of 5 subjects.

Changes in osmotic fragility of Rbc and lipid contents in the cell membrane and the plasma during the course of the dive were not pressure dependent. These facts indicate that the cell membrane appears to maintain a normal chemical structure at 31 ATA. Statistically significant correlations between osmotic fragility and lipid contents in red cells, and between osmotic fragility and the plasma level of cholesterol were observed in the present experiment, however, these correlationships were not specific in the hyperbaric environment. These significant correlations have been observed in various conditions such as nutritional disorders (malnutrition), thermal stress, and changes in the splenic function. The present observation supports the fact that a significant correlation of osmotic fragility and lipids also existed within intra- and interindividual fluctuations during the course of the dive. In conclusion, the present experiment revealed that a prolonged exposure to 31 ATA neither changed the lipid contents of Rbc and the plasma, nor affected the osmotic fragility of $\mathrm{Rbc}$.

\section{References}

van Beaumont, W. (1972) : Evaluation of hemoconcentration from hematocrit measurements. J. Appl. Physiol., $32: 712-713$.

Brewster, E., Collins, S., Funnel, G.R. et al. (1976) : The effect of high pressure on the hemolysis of red blood cells. Undersea Biomed. Res., 3: 151-155.

Fenn, W.J. \& Boschen, V.P. (1971) : Haemolysis under hydrostatic pressure. Proc. Soc. Exp. Bio. Med., 137 : $847-916$.

Folch, J., Lee, M. \& Stanley, S.G.H. (1957) : A simple method for the isolation and purification of total lipides from animal tissues. J. Biol. Chem., 26: 497-509.

Goldinger, J.M., Kang, B.S., Choo, Y.E. et al. (1980) : Effect of hydrostatic pressure on ion transport and metabolism in human erythrocytes. J. Appl. Physiol.: Respirat. Environ. Exercise Physiol., 49: 224-231.

Hall, A.C. \& Macdonald, A.G. (1979) : The effects of hydrostatic pressure on the osmotic fragility of erythrocytes and their protection by pentanol. J. Physiol., 295: 42-43.

Hisaoka, F. \& Shiraki, K. (1974): The effect of splenectomy and dietary protein on erythrocyte survival and fragility in rats. J. Nutr. Sci. Vitaminol., $20: 375-382$.

Jacey, M.J., Gonzales, A. \& Tappan, D.V. (1977) : Hematologic changes after two exposures to 6.7 ATA air at three-day intervals. J. Appl. Physiol.: Respirat. Environ. Exercise Physiol., 42 : 838-844.

Kuiper, P.J.C., Livne, A. \& Meyerstein, N. (1971) : Changes in lipid composition and osmotic fragility of erythrocyte of hamster induced by heat exposure. Biochem. Biophys. Acta, 248: 300-305. 
Macdonald, A.G. (1981): Molecular and cellular effects of hydrostatic pressure; A physiologist's view. In: Underwater Physiology VII. (Bachrach, A.J. \& Matzen, M.M., ed.). Undersea Med. Soc. Inc., Bethesda. pp. 567-575.

Mengel, C.E: \& Kann, H.E., Jr. (1966) : Effects of in vivo hyperoxia on erythrocyte : III. In vivo peroxidation of erythrocyte lipid. J. Clin. Invest., 45 : 1150-1158.

Nakayama, H. Hong, S.K., Claybaugh, J.R. et al. (1981) : Energy and body fluid balance during a 14-day dry saturation dive at 31 ATA (Seadragon IV). In: Underwater Physiology VII. (Bachrach, A.J. \& Matzen, M.M., ed.). Undersea Med. Soc. Inc., Bethesda. pp. 541-554.

Philp, R.B. (1974) : A review of blood changes associated with compression-decompression : Relationship to decompression sickness. Undersea Biomed. Res., 1: 117-150.

Sagawa, S. \& Shiraki, K. (1978a) : Role of lipids in stabilizing red cells in rats. J. Nutr. Sci. Vitaminol., 24 : $57-65$.

Sagawa, S. \& Shiraki, K. (1978b) : Influence of dietary protein on the properties on the red cell membrane in intact and splenectomized rats. J. Nutr. Sci. Vitaminol., 24: 311-322.

Sagawa, S. \& Shiraki, K. (1980) : Changes of osmotic fragility of red blood cells due to repletion or depletion of cholesterol in human and rat red cells in vitro. J. Nutr. Sci. Vitaminol., 26: 161-169.

Saliman, P.M. (1964) : A new digestion reagent for the determination of microgram quantities of phosphorus in organic compounds. Anal. Chem., 36: 112-114.

Shiraki, K., Sagawa, S. \& Kulapongs, P. (1976): Changes in lipids and osmotic fragility of erythrocytes in protein-calorie malnutrition. In: Topics in Hematology. (Seno, S., Takaku, F., Irino, S., ed.) Excerpta Med., Amsterdam. pp. 977-979.

Skipski, V.P., Peterson, R.F. \& Barclay, M. (1964): Quantitative analysis of phospholipids by thin-layer chromatography. Biochem. J., $90: 374-378$.

Smith, A. \& Tappan, D.V. (1975) : Erythrocyte fragility changes resulting from short exposure to 6.7 ATA. NAVSUB-MEDRSCHLAB Rept., $811: 1-8$.

Yoshimura, H., Inoue, T., Yamada, T. et al. (1980): Anemia during hard physical training (sports anemia) and its causal mechanism with special reference to protein nutrition. Wld. Rev. Nutr. Diet., 35 : 1-86.

Zack, B., Dickenman, R.C, White, E.G. et al. (1954) : Rapid estimation of free and total cholesterol. Am. J. Clin. Path., 24 : 1307-1315.

Zarkowsky, H.S., Mohandas, N., Speaker, C.B. et al. (1975) : A congenital haemalytic anemia with thermal sensitivity of the erythrocyte membrane. Br. J. Haematol., $29: 537-543$. 
14 日間，31 気圧での滞在と赤血球脆弱性

白木 啓三 1 佐川 寿栄子 1 -今田 育秀 1 - 中山 英明 2

産業医科大学第二生理学教室 ${ }^{2}$ 産業医科大学高気圧治療部

要 旨： 31 気圧にて 14 日間飽和潜水を行った際の血液学的な変化および赤血球の脆弱性を赤血球膜 の脂質との関係において研究した，31 気圧では当初血液濃縮がみられ，これは尿量の增加 の結果であると推定された，赤血球の脆弱性および膜脂質構成成分は日による変動がかなり 見られたが，これらの変化は気圧の変化とは直接連動しなかった．赤血球の脆弱性と膜の phosphatidyl choline 分画および血獎中の総 cholesterol 量とは有意の相関がみられた. 今 回みられたこのような相関は気圧の変化によってのみみられるものではなく，むしろ個人差, 日変動等の要因によっても起こる脆弱性の変化は膜および血漿の脂質成分の変化によって惹 起するという事奏を裏づけたものである.今回の実験ではヒトが 31 気圧へリウム環境に長 時間滞在しても血球の機能には変化がみられないことを実証した。

J. UOEH (産業医大誌), 5 ( 1 ): 35-47 (1983) 